\title{
FRICTION STIR WELDING of MAGNESIUM AlLOYS - A REVIEW
}

\author{
Unnikrishnan $\mathrm{M} \mathrm{A}^{1}$ Edwin Raja Dhas ${ }^{2}$ \\ ${ }^{1}$ Department of Mechanical Engineering, Noorul Islam University,Thuckalay, 629180, \\ Tamil Nadu \\ ${ }^{2}$ Department of Automobile Engineering, Noorul Islam University, Thuckalay, 629180, \\ Tamil Nadu
}

\begin{abstract}
:
The selection of proper material for each application is a critical part in every manufacturing industry. In the field of aerospace and automobile the major requirement is light weight yet strong material which can possess every aspect of design parameters. Magnesium alloy one of the major raw material used in these industries due to its light weight, good thermal conductivity etc. Also Friction stir welding is the joining process that is being used in these industries as it is a solid state joining process. This paper gives a detailed review about Friction Stir welding of $\mathrm{Mg}$ alloys. The review period is considered from 2009 to 2015.A detailed review about Friction stir welding of Mg alloys has not been done before in this manner. This review work may be a ready reference for subsequent researchers.
\end{abstract}

\section{KEYWORDS:}

Friction stir welding, Magnesium alloy

\section{INTRODUCTION}

The modern technologies are gaining more and more importance in almost every field and Manufacturing industry not an exception. .Welding has been a constant part of every manufacturing industry in which Automobile industry is the major partner. More and more research has been going on related to welding techniques [1]. Friction stir welding is one of the latest welding techniques that have found a major part in automotive sector. Friction stir welding is a solid state joining technique invented and developed by The Welding Institute (TWI), UK. Firstly Friction stir welding was used for welding Aluminium alloys. Later had found application in welding Magnesium, Copper alloys etc. Some materials such as Aluminium 7xxx series, 2xxx series which were considered un weld able are now possible with Friction stir welding.

In FSW a cylindrical shouldered tool with a profiled pin is rotated and plunged into the joint area between two plates. For proper welding the plates must be clamped during the process.[1] Friction Stir welding is a solid state joining process and the heat generated during the rotation of the tool will cause the materials to get joined without reaching melting point. The plasticized material is transferred to the trailing edge of the tool pin, is forged with the tool shoulder and pin. 


\section{MAGNESIUM ALLOY}

Magnesium alloys are promising alternatives for Aluminium, steel etc. due to its outstanding properties. The stiffness to weight ratio, low density, high damping capacity etc is some of them. These properties had enabled them to become a major part of automotive industry. A reduction of $20-70 \%$ of total weight of the components can be achieved. $\mathrm{Mg}$ alloys are having a hexagonal lattice structure and therefore during plastic deformation there are some complications when compared to $\mathrm{Cu}$ etc.[2] Mechanical properties of $\mathrm{Mg}$ alloys are improved by adding rare earth elements. $\mathrm{Mg}$ alloys are characterized with low melting point, large thermal expansion and therefore welding of $\mathrm{Mg}$ alloys using conventional methods will lead to cracks, pores etc. Commercial $\mathrm{Mg}$ alloys contain $\mathrm{Al}(3-13 \mathrm{wt} \%) \mathrm{Mn}(0.1-0.4 \mathrm{wt} \%), \mathrm{Zn}(0.5-3 \mathrm{wt} \%)$ and some are hardeneble by heat treatment. $\mathrm{Mg}$ alloys are often designated by 2 numbers. Letters denote the main alloying elements and numbers represents nominal composition of alloying elements. Addition of zinc and calcium alloys will increase the chance of occurring solidification cracking. Addition of zinc upto $2 \%$ is normal but further increase will cause poor weld ability.

\section{FRICTION STIR WELDING}

Friction Stir Welding (FSW) is an innovative solid state welding technique which was first invented by The Welding Institute (TWI), UK in 1991.This technique was developed aiming Aluminium alloys but later it had found profound application in welding of $\mathrm{Mg}$ alloys, $\mathrm{Cu}$ alloys etc.[3] These alloys once considered unweldable are now possible by FSW.This method utilizes a non-consumable rotating tool to produce frictional heat and thus producing plastic deformation at the location of welding. FSW process consists of a rotating tool with a shoulder and probe arrangement. The heat is developed due to friction between the work piece surface and the tool[3]. The heat thus produced is used to soften the work piece before reaching its melting point.

The heat generated during the process is about $80-90 \%$ of the melting temperature. With FSW traditional components current and voltage are not present as the heat input is purely mechanical replaced by force, friction etc. The quality of an FSW joint is always better than other fusion welding processes. In this process the FSW material consists of four distinct microstructural zones namely Nugget zone (NZ),Thermo mechanically affected zone(TMAZ),Heat affected zone (HAZ) and Base material (BM).The process parameters chosen during FSW process has great influence on these zones.[4]

\subsection{Welding Parameters}

The welding parameters are key players during every welding technique and FSW is no exception. Proper selection of welding parameters influences the final weld quality and resulting microstructure. In FSW the parameters chosen are tool rotational speed, welding speed, tilting angle, pin profiles, axial down force (Z-axis) etc. The down force will ensure the generation of frictional heat to soften the material. An increase in the tool rotational speed and decrease in tool travel speed will cause a hotter weld. For a good quality weld the welding temperature must be sufficient and it should not be too less or too high. Some other influencing parameters are the work material dimension, chemical Composition etc. The tool rotational time is another 
important factor though look less important it plays a major part in the weld microstructure. The more the welding tool is rotated and moved the more will the microstructural change will take place. The grain arrangement will change abruptly with increasing rotations. Proper fixtures are needed for work material arrangement otherwise during tool rotation there are chances for misalignment. Majority of studies are concentrated on tool rotational speed, welding speed, tool pin profile and axial force.

\subsection{Welding tool}

Welding tool design is critical in FSW processes Optimizing tool geometry will produce more heat there by breaking the oxide layer, higher welding speeds etc. Tool material should possess high hardness at elevated temperatures and should maintain that hardness till the end of the process. Weld quality and tool wear are two important considerations in the selection of tool material, the properties of which may affect the weld quality by influencing heat generation and dissipation. The weld microstructure may also be affected as a result of interaction with eroded tool material.H13 tool steel is usually used for FSW.The shape of the pin design depends on the material thickness, ability to break the oxide layer formation, heat generation etc. A nonprofiled tool is capable of producing enough heat. The various types of pin profiles used are cylindrical, cylindrical threaded pin, conical etc. The shape of pin profile greatly influences the final weld microstructure, grain refinement etc. FSW has several advantages over conventional welding techniques. Bending and tensile tests can be done rigidly and from the economical point of view FSW has many cost reducing benefits such as low energy consumption, no welding consumables etc.

This review mainly focuses on FSW of Mg alloys. Such a review in this area has not been done in this manner yet. Effort has been done to identify the FSW process parameters on $\mathrm{Mg}$ alloys and its resultant details. The period of review was from 2009-2015.The influence of various process parameters on final weld quality, microstructure analysis, Optimization techniques used etc are focused on the paper. Thorough literature review has been done to point out every single detail in FSW of Mg alloys. This paper will be helpful for forthcoming researchers. 
Advances in Materials Science and Engineering: An International Journal (MSEJ), Vol. 2, No. 4, December 2015

Table I Summary of Friction Sitr velding of Magnesium alloys Review

\begin{tabular}{|c|c|c|c|c|c|}
\hline YearAuthor(s) & Objective (s) & Work piece material & $\begin{array}{l}\text { Tool matcrial \& } \\
\text { Desiggn }\end{array}$ & Process parameters \& levels & Remarks \\
\hline $\begin{array}{l}2015 \text { / Prakash kumars } \\
\text { Sahu and } \\
\text { Sulhomay pal }\end{array}$ & $\begin{array}{l}\text { Paraneter } \\
\text { optimization using } \\
\text { Taguchi's Grey } \\
\text { relational Analysis }\end{array}$ & 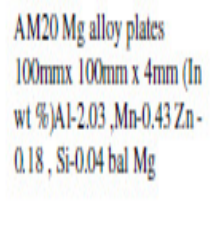 & $\begin{array}{l}\text { Hll3 } 3 \text { tool stecl } \\
\text { SD : } 16: 24 \mathrm{~mm} \\
\text { PD) } 6 \mathrm{~mm} \\
\text { PL: } 3.5 \mathrm{~mm}\end{array}$ & $\begin{array}{l}\text { WS: } 63-132 \mathrm{~mm} \text { min } \\
\text { TRS:600- } 1100 \mathrm{rrv} / \mathrm{min} \\
\text { SDD: } 16-24 \mathrm{~mm} \\
\text { PLD:D:0.12.0.21 }\end{array}$ & $\begin{array}{l}\text { Shoulder diameter and } \\
\text { plunge depth were the most } \\
\text { influencing parameters. }\end{array}$ \\
\hline $\begin{array}{l}\text { 2015.5N Jajaganesh } \\
\text { and P.Servel }\end{array}$ & $\begin{array}{l}\text { Influence of process } \\
\text { paranters on } \\
\text { microstructural and } \\
\text { mechanical properties }\end{array}$ & 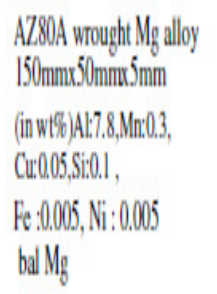 & $\begin{array}{l}\text { Mi35 HSS tool } \\
\text { SD: } 12 \mathrm{~mm} \\
\text { PD: }: 7.4 \mathrm{~mm} \\
\text { PL: } 4.75 \mathrm{~mm}\end{array}$ & $\begin{array}{l}\text { TRS: } 500-1000 \text { rew/min } \\
\text { Feed: } 0.5 \text { - } 3 \mathrm{~mm} / \mathrm{min} \\
\text { Axial force: } 5 \mathrm{KN}\end{array}$ & $\begin{array}{l}\text { Good quality wedds were } \\
\text { obtained. Large coarse } \\
\text { grauns ane converted to fine } \\
\text { grauns in stimed zone thes } \\
\text { leading to superior } \\
\text { mechanical properties. }\end{array}$ \\
\hline $\begin{array}{l}2015 / \text { / Bhulyy } \\
\text { Srinvisa Naik et al. }\end{array}$ & $\begin{array}{l}\text { To find out the } \\
\text { residual stresses and } \\
\text { tensile properties }\end{array}$ & 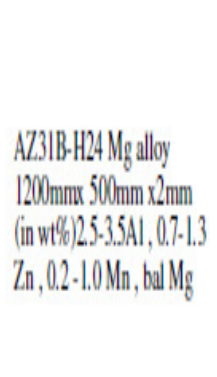 & $\begin{array}{l}\text { H13 tool sced } \\
\text { SD: } 19.0 .5 \mathrm{~mm} \\
\text { PD: } 6.35 \mathrm{~mm} \\
\text { TL: } 4.45 \mathrm{~mm} \\
\text { TS: } 1.27 \mathrm{~mm} \\
\text { P:0.8 thrad } \\
\text { Tilt angle }: 0.50 \\
\text { PLLD: } 0.25 \mathrm{~mm}\end{array}$ & $\begin{array}{l}\text { WS: } 10 \text { or } 20 \mathrm{~mm} / \mathrm{min} \\
\text { TRS: } 1000 \text { or } 1500 \mathrm{rev} / \mathrm{min}\end{array}$ & $\begin{array}{l}\text { Higher WS and lower TRS } \\
\text { kedid to higher fallure load } \\
\text { Shear tensile fracture } \\
\text { intitates around the } \\
\text { region of SIITMAZ }\end{array}$ \\
\hline 2015/ S.Mironovect al. & $\begin{array}{l}\text { Microstructure evolution } \\
\text { during FSW }\end{array}$ & $\begin{array}{l}\text { AZ31 Mg alloy } \\
\text { Amm thick shects } \\
\text { (in wt\%) Mg.-3.0A1-1.0Zn }\end{array}$ & $\begin{array}{l}\text { Tool sted } \\
\text { SD: } 15 \text { mm (connewe) } \\
\text { PL: } 37 \mathrm{~mm} \\
\quad \text { (M5 threaded) } \\
\text { Tilt angle: } 3^{\circ} \\
\text { PLD: } 3.5 \mathrm{~mm}\end{array}$ & $\begin{array}{l}\text { WT:0.57-0.85 T T } \\
\text { TRS: } 300-3000 \mathrm{rpm} \\
\text { WS: } 200 \mathrm{~mm} / \mathrm{min}\end{array}$ & $\begin{array}{l}\text { Lowening of grain } \\
\text { boundary misorientation } \\
\text { (frain convergence ) } \\
\text { Lowcring of temperature } \\
\text { leads to increase in tool } \\
\text { load. }\end{array}$ \\
\hline
\end{tabular}


Advances in Materials Science and Engineering: An International Journal (MSEJ), Vol. 2, No. 4, December 2015

\begin{tabular}{|c|c|c|c|c|c|}
\hline Year/Author(s) & Objective (s) & Work pice material & $\begin{array}{l}\text { Tool mattrial \& } \\
\text { Design }\end{array}$ & Process parancers \& levels & Remarks \\
\hline $\begin{array}{l}2014 / \text { Sevvel. Pa and } \\
\text { Jaganesh V }\end{array}$ & $\begin{array}{l}\text { Mechanical properties } \\
\text { charectanisation and } \\
\text { microstructural analysis } \\
\text { through optimized process } \\
\text { parameters }\end{array}$ & 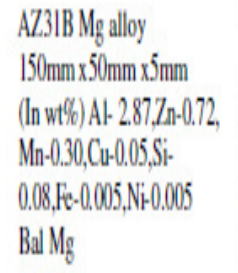 & $\begin{array}{l}\text { Taper cylindrical pin } \\
\text { profiled HSS tool(M35 } \\
\text { gradc) } \\
\text { D/dratio: } 3 \\
\text { PD: } 4 \mathrm{~mm} \\
\text { PL: } 4.75 \mathrm{~mm}\end{array}$ & $\begin{array}{l}\text { TRS : 500-1000/pm } \\
\text { WS : } 0.5 .3 .30 \mathrm{~mm} / \mathrm{min} \\
\text { AF : } 3 \mathrm{KN}\end{array}$ & $\begin{array}{l}\text { Defect free joints are } \\
\text { obtained \& microstructure } \\
\text { has been improved also } \\
\text { tensile strength and yicld } \\
\text { strength. }\end{array}$ \\
\hline 2014/ B.S.Naik et al & $\begin{array}{l}\text { Characterization of micro } \\
\text { structur \& mechanical } \\
\text { propertics }\end{array}$ & 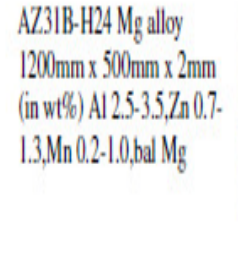 & $\begin{array}{l}\text { HI3 tool stecl.50 HRC } \\
\text { SD: } 19.05 \mathrm{~mm} \\
\text { PD) } 6.35 \mathrm{~mm} \\
\text { TL: } 4.45 \mathrm{~mm} \\
\text { Pitch: } 0.8 \mathrm{threadmm}\end{array}$ & $\begin{array}{l}\text { WS : } 10 \& 20 \mathrm{~mm} / \mathrm{s} \\
\text { TRS: } 1000 \& 1500 \mathrm{rpm} \\
\text { WP : } 0.4 .1 .2 \mathrm{~mm} / \mathrm{rv}\end{array}$ & $\begin{array}{l}\text { Grain coarsening wes seen } \\
\text { in SZ,TMAZZ,HAZZTexture } \\
\text { changes had taken plaxe in } \\
\text { the stir zonc.WS and TRS } \\
\text { has strong effect on falure } \\
\text { loads of lap welds. }\end{array}$ \\
\hline $2014 /$ Yong tha e ct al & $\begin{array}{l}\text { Microstructure analysis and } \\
\text { Mechanical propertics } \\
\text { testing }\end{array}$ & 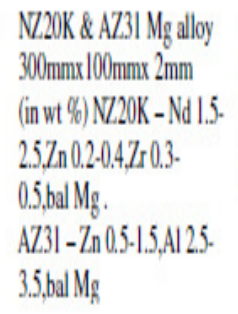 & $\begin{array}{l}\text { Hl3 tool stecl } \\
\text { SD) : Imm(concave) } \\
\text { PD: } 4 \mathrm{~mm} \\
\text { PL: } 2 \mathrm{~mm} \\
\text { Tilt angle }: 25^{\circ}\end{array}$ & $\begin{array}{l}\text { TRS: } 1300 \mathrm{~mm} \\
\text { WS: } 60 \mathrm{~mm} / \min \end{array}$ & $\begin{array}{l}\text { Uniform distribution of } \\
\text { grains A decrease in } \\
\text { Tensile strength and UTS } \\
\text { is observed with respect to } \\
\text { temperature. Increas. }\end{array}$ \\
\hline 2014/A.lugender et.al & $\begin{array}{l}\text { Influence of Rotational } \\
\text { speed on microstructure } \\
\text { and mechanical properties. }\end{array}$ & 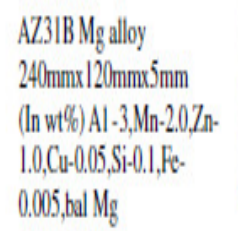 & $\begin{array}{l}\text { HSS tool (TT) } \\
\text { SD : I8mm } \\
\text { PD : } 6 \mathrm{~mm} \\
\text { PL: } 4.8 \mathrm{~mm} \\
\text { Tilt angk :2.50 }\end{array}$ & $\begin{array}{l}\text { TRS : } 900,1120,1400,1800 \mathrm{rpm} \\
\text { WS : } 40 \mathrm{~mm} / \min \end{array}$ & $\begin{array}{l}\text { TRS has a significant } \\
\text { influence on grain } \\
\text { refinement. Optimum } \\
\text { results wer obtained at an } \\
\text { rpm of } 1400 \text {. }\end{array}$ \\
\hline
\end{tabular}


Advances in Materials Science and Engineering: An International Journal (MSEJ), Vol. 2, No. 4, December 2015

\begin{tabular}{|c|c|c|c|c|c|}
\hline Year/Author(s) & Objective (s) & Work picce material & $\begin{array}{l}\text { Tool material \& } \\
\text { Design }\end{array}$ & Process paramcters \& kevels & Remarks \\
\hline 2014/1/nderieet Singh et al. & $\begin{array}{l}\text { Effect on welding } \\
\text { parameters on weld joints } \\
\text { During lap welding }\end{array}$ & 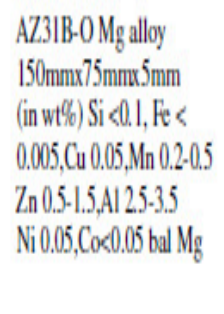 & $\begin{array}{l}\text { High cabbon high } \\
\text { chromium steel } \\
\text { (Left Hand thraded) } \\
\text { SD: } 18-20 \mathrm{~mm} \\
\text { PD: } 7 \mathrm{~mm} \\
\text { PL: 4.8mm } \\
\text { D/d ratio: } 256 \& 3\end{array}$ & $\begin{array}{l}\text { WS: } 40,60 \mathrm{~mm} / \mathrm{min} \\
\text { TRS: } 1200,1050 \mathrm{rmm} \\
\text { WP : } 0.00202 \mathrm{~mm} / \mathrm{rr}-0.0500 \\
\text { rev/min } \\
\text { SD : } 18 \mathrm{~mm} \& 20 \mathrm{~mm}\end{array}$ & $\begin{array}{l}\text { High weld pitch yields high } \\
\text { tensile sitrenghth.at } 0.050 \\
\text { mm/rev } \\
\text { Proper grain refinement } \\
\text { impact toughness got } \\
\text { improved in joints }\end{array}$ \\
\hline 2013/S. Reajajumare tal. & $\begin{array}{l}\text { To study the effect of } \\
\text { process paranceters on weld } \\
\text { quality }\end{array}$ & $\begin{array}{l}\text { AZ61A Mg alloy } \\
300 \mathrm{mmx} 150 \mathrm{~mm} x 6 \mathrm{~mm} \\
\text { (in wt } \% \text { ) Al } 5.96, \\
\mathrm{Zn} 1.28, \mathrm{Mn} 0.17, \text { bal Mg }\end{array}$ & 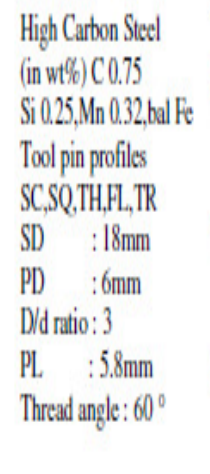 & $\begin{array}{l}\text { Tool pin profiles } \\
\text { SC,SO,TH,FL,TR } \\
\text { TRS: } 800 \text { - } 1600 \text { rpm } \\
\text { (Varying on types of } \\
\text { tool pin) } \\
\text { WS : } 30 \text { - } 150 \text { mm/min } \\
\text { (Vaying on types of } \\
\text { tool pin) } \\
\text { AF : } 3.7 \mathrm{KN} \\
\text { (Varying on types of } \\
\text { tool pin) }\end{array}$ & $\begin{array}{l}\text { Maximum tensile strength } \\
\text { was obtained by using } \\
\text { threaded cylindrical pin } \\
\text { with TRS of } 1194 \mathrm{mmm}, \mathrm{WS} \\
\text { of } 92.19 \mathrm{~mm} / \mathrm{min}, \text { AF of } \\
5.05 \mathrm{KN} \text {. }\end{array}$ \\
\hline $\begin{array}{l}\text { 2012/ S.H.Chowdhury et } \\
\text { al. }\end{array}$ & $\begin{array}{l}\text { Microstructure andyyis and } \\
\text { properties testing on joints }\end{array}$ & $\begin{array}{l}\text { AZ3IB-H24 Mg alloy } \\
2 \mathrm{~mm} \text { in thickness } \\
\text { (in wt } \% \text { ) AI } 2.5 .3 .5, \mathrm{zn} \\
0.7-1.3, \mathrm{Mn} 0.2 \cdot 1.0 \text {, bal } \\
\mathrm{Mg}\end{array}$ & $\begin{array}{l}\text { Tool steel with left } \\
\text { hand threaded pin } \\
\text { PL: } 1.65 \mathrm{~mm} \\
\text { PD: }: 3.175 \mathrm{~mm}\end{array}$ & $\begin{array}{l}\text { WS: } 5-20 \mathrm{~mm} / \mathrm{s} \\
\text { TRS : } 1000-2000 \mathrm{rpm}\end{array}$ & $\begin{array}{l}\text { Texture weakened due to } \\
\text { increased TRS and } \\
\text { decreasing WS.WS and } \\
\text { TRS has gratat influence on } \\
\text { the Yield strength than the } \\
\text { UTS. }\end{array}$ \\
\hline
\end{tabular}




\begin{tabular}{|c|c|c|c|c|c|c|}
\hline$Y_{\text {earl/Author }(s)}$ & Objective (s) & \multicolumn{2}{|c|}{ Work picec material } & $\begin{array}{l}\text { Tool material \& } \\
\text { Design }\end{array}$ & Process parameters \& kvels & Remarks \\
\hline $\begin{array}{l}\text { 2011/A.Razal Rose et } \\
\text { al. }\end{array}$ & $\begin{array}{l}\text { To calculatet the } \\
\text { influene of welding } \\
\text { speed on Tensile } \\
\text { propertics. }\end{array}$ & \multicolumn{2}{|c|}{ 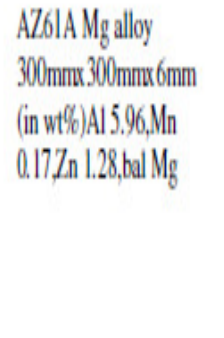 } & $\begin{array}{l}\text { High Carbon sted } \\
\text { PD: } 6 \mathrm{~mm} \\
\text { SD): } 18 \mathrm{~mm} \\
\text { PL: } 59 \mathrm{~mm}\end{array}$ & $\begin{array}{l}\text { TRS : } 1200 \mathrm{~mm} \\
\text { WS : } 30-150 \mathrm{~mm} / \mathrm{min} \\
\text { AF : } 5 \mathrm{KN}\end{array}$ & $\begin{array}{l}\text { WS has maximum } \\
\text { influence on microstructure } \\
\text { and tensile properties. } \\
\text { Maximum tensile strength } \\
\text { was obtaind at TRS of } \\
1200 \text { rmm and WS of } \\
90 \mathrm{~mm} / \mathrm{min} \text {. }\end{array}$ \\
\hline $\begin{array}{l}\text { 2010/K.L.Hariknishna et } \\
\text { al. }\end{array}$ & $\begin{array}{l}\text { Effect of process } \\
\text { paranneters on weld } \\
\text { quality }\end{array}$ & \multicolumn{2}{|c|}{$\begin{array}{l}\text { ZM2I Mg alloy } \\
25 \text { mm in thickness } \\
\text { (in wt } \%) \text { Mg - } 27 \mathrm{n} \cdot 1 \mathrm{Mg}\end{array}$} & $\begin{array}{l}\text { Hl3 tool steel } \\
\text { Threaded pin (LH) } \\
\text { PD): } 5 \mathrm{~mm} \\
\text { PL: } 4.5 \mathrm{~mm} \\
\text { SD : } 15 \mathrm{~mm}\end{array}$ & $\begin{array}{l}\text { TRS : } 450,600 \mathrm{~mm} \\
\text { WS : } 20.45 \mathrm{~mm} / \mathrm{min} \\
\text { PL.D: } 0.10 .0 . \mathrm{mm} \\
\text { Tilt angt : } 2^{\circ}\end{array}$ & $\begin{array}{l}\text { Giran size incressed at the } \\
\text { Heat affected zone and } \\
\text { Nugget zone with respect } \\
\text { to thickness. }\end{array}$ \\
\hline 2009/G.Padmanaban et ad. & $\begin{array}{l}\text { Investigation of process } \\
\text { parameters on final weld } \\
\text { quality and nechunical } \\
\text { propertics }\end{array}$ & \multicolumn{2}{|c|}{$\begin{array}{l}\text { AZ3IB Mg alloy } \\
220 \mathrm{~mm} \times 7 \text { mmx } 6 \text { mmm }\end{array}$} & $\begin{array}{l}\text { High carbon sted } \\
\text { (Threaddd pin) } \\
\text { PL: } 5.7 \mathrm{~mm} \\
\text { SD : } 18 \mathrm{~mm} \\
\text { PD : 6mm } \\
\text { D/d ratio: } 3 \\
\text { (in wt \%) } \\
\text { C0.75,Si } 0.25 \text {, } \\
\text { Mn } 0.32\end{array}$ & $\begin{array}{l}\text { TRS : } 1000-2000 \mathrm{rpm} \\
\text { WS : } 0.37-2.25 \mathrm{~mm} / \mathrm{s} \\
\text { AF : } 2,3,4 \mathrm{KN}\end{array}$ & $\begin{array}{l}\text { Higher tensile propertices } \\
\text { wee obtained with a TR of } \\
1600 \mathrm{pmm}, \text { WSO.67 mm/s } \\
\text { and AF } 3 \mathrm{KN} \text {. }\end{array}$ \\
\hline PD) :Pin Diameter & \multicolumn{2}{|c|}{ WS : Welding Speed } & \multicolumn{2}{|c|}{ WP : Weld Pitch } & TR :Triangular & \\
\hline SD：Shoulder Diameter & \multicolumn{2}{|c|}{ AF :Axial Force } & \multicolumn{2}{|c|}{ SC : Straight Cylindrical } & LH :Left Handed & \\
\hline PL : :PinLength & \multicolumn{2}{|c|}{ TL : Thread Length } & \multicolumn{2}{|c|}{ SQ : Square } & NZ : Nugget Zone & \\
\hline PLD : Plunge Depth & \multicolumn{2}{|c|}{ TS :Thread Spacing } & \multicolumn{2}{|c|}{ TH :ThreadedCylindrical } & HAZ : Heat AffectedZone & \\
\hline TRS : Tool Rotational Sp & \multicolumn{2}{|c|}{ WT : Weld Temperature } & F : Flute & & TMAZ: thermo Mechanicall & AffectedZone \\
\hline
\end{tabular}


The review of Friction stir welding of $\mathrm{Mg}$ alloys is in between 2009 and 2015.early researches were concentrated on the effect of selected process parameters on final weld quality and on mechanical properties.G.Padmanabhan and V.Balasubramanian [14] in 2009 done experimental investigations on fourteen joints using different levels of Tool rotational speed, welding speed etc. A tool rotational speed of $1600 \mathrm{rpm}$, welding speed of $0.67 \mathrm{~mm} / \mathrm{sec}$ and an axial force of $3 \mathrm{KN}$ yielded superior joints. The tensile properties of the welded joints were also been found out and optimum values were obtained. Formation of finer grains, optimum level of heat generation and higher hardness were the main reasons for increased tensile strength.K.L.Harikrishna et.al.[13] in 2010 concentrated on Friction stir welding of ZM $21 \mathrm{Mg}$ alloy which is having a nominal composition of $\mathrm{Mg}-2-\mathrm{Zn}-1 \mathrm{Mn}$ (in wt. \%).Proper selection of process parameters obtained a defect free good grain structured welds. Bend performance of the welds was satisfactory. The work reveals that friction stir welding is possible for joining $\mathrm{ZM} 21 \mathrm{Mg}$ alloys for thickness up to $25 \mathrm{~mm}$.

A.Razal Rose et .al.[12] work in 2011 is focusing on the influences of welding speed on tensile properties of Friction stir welded AZ61A Mg alloy.( in wt. \%, Al -5.9,Mn-0.17,Zn-1.28,bal $\mathrm{Mg}$ )Welding speed has been found to have great influence on Grain size of stir zone, hardness etc. Among the selected values a tool rotational speed of $1200 \mathrm{rpm}$, axial force of $5 \mathrm{KN}$ exhibited maximum tensile strength.S.H.Chowdhury et.al.[11] in 2012 analyzed the influence of process parameters during friction stir welding of AZ31B-H24 Mg alloy(wt.\% Al 2.5-3.5, Zn 0.7-1.3,Mn $0.2-1.0 \mathrm{bal} \mathrm{Mg}$ ) Tool having a pin length of $1.65 \mathrm{~mm}$ and pin diameter of $3.175 \mathrm{~mm}$ is used. Lowest hardness was obtained at the center of Stir zone.The welding speed and rotational rate had stronger influence on yield strength .A welding speed of $20 \mathrm{~mm} / \mathrm{s}$, rotational rat of $1000 \mathrm{rpm}$ produced higher yield strength welds.S.Rajakumar et.al [10] in 2013 showed a relationship between process parameters and tensile strength. Response surface methodology was used for the formation of empirical relationship.AZ61A $\mathrm{Mg}$ alloy was used for experimentation (in wt.

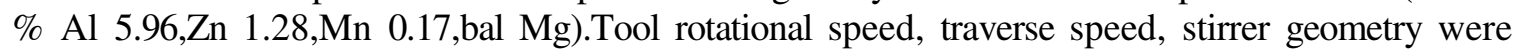
considered. Optimization was done with the help of Response surface methodology. A tool rotational speed of $1194 \mathrm{rpm}$, welding speed of $92.19 \mathrm{~mm} / \mathrm{min}$, axial force of $5.05 \mathrm{KN}$ yielded maximum tensile strength.Inderjeet Singh et.al [9] in 2014 studied the effects of welding parameters on similar friction stir welded joints of AZ31B-O $\mathrm{Mg}$ alloy (in wt. \% $\mathrm{Si}<0.1, \mathrm{Fe} /, 0.005, \mathrm{Cu} \quad 0.05, \mathrm{Mn} \quad 0.2-\quad 0.5, \mathrm{Zn} \quad 0.5-1.5, \mathrm{Al} \quad 2.5-3.5, \mathrm{Ni} \quad 0.05, \mathrm{Co} /, 0.05, \mathrm{bal} \quad \mathrm{Mg}) . \mathrm{The}$ mechanical properties and microstructure were investigated. At a high welding pitch of $0.050 \mathrm{~mm} / \mathrm{rev}$ with a shoulder diameter of $20 \mathrm{~mm}$ yielded a $91 \%$ increase in tensile strength that the base metal. All joints show an improvement in impact toughness, a maximum harness value of $67.25 \mathrm{Hv}$ was observed at the same weld pitch and shoulder diameter.S.Ugender et.al. [8] in 2014 experimented on AZ31B Mg alloy to find out the influences of welding parameters on

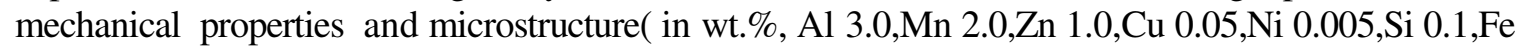
$0.005 \mathrm{bal} \mathrm{Mg}$ ).The friction stir welding had been carried out at 900rpm,1120rpm,1400rpm and 1800rpm with tool materials High speed steel and stainless steel. The micro hardness values obtained had shown an increase at low rotational speeds. A lowering of tensile strength was obtained at rotational speeds of 1400rpmand $1800 \mathrm{rpm}$.

Yong Zhao et.al. [7] in 2014 compared the micro hardness values and tensile properties of NZ20K (Mg-2Nd-0.3Zn-0.4Zr) and AZ31 Mg alloy at room temperature and $200^{\circ} \mathrm{C} . \mathrm{NZ20K}$ had a 
chemical composition of (in wt.\%) $\mathrm{Nd} 1.5-2.5, \mathrm{Zn} 0.2-0.4, \mathrm{Zr} 0.3-0.5$,bal $\mathrm{Mg}$ and AZ31 having a chemical composition (in wt.\%) $\mathrm{Zn}$ 0.5-1.5, Al 2.5-3.5, bal Mg. Tool rotational speed and welding speed were the selected process parameters with a pin diameter of $6 \mathrm{~mm}$,pin length of $4.8 \mathrm{~mm}$,shoulder diameter of $18 \mathrm{~mm}$ of high speed steel material with a tilt angle of $2.5^{\circ}$.A defect free joint was obtained under 13oorpm and $60 \mathrm{~mm} / \mathrm{min}$. The ultimate tensile strength showed a decrease in value at $200^{\circ} \mathrm{C}$ than at room temperature. The hardness of the joint at Nugget zone had improved from that at the base metal.B.S.Naik et.al.[6] in 2014 had done a detailed investigation on texture development during Friction stir lap welding of AZ31B-H24 Mg alloy( in wt.\% $\mathrm{Al} 2.5-3.5, \mathrm{Zn} 0.7-1.3, \mathrm{Mn} 0.2-1.0 \mathrm{bal} \mathrm{Mg}$ ) at varying tool rotational speeds and welding speeds. H13 tool steel was used with a pin diameter $6.35 \mathrm{~mm}$, shoulder diameter of $19.05 \mathrm{~mm}$, pitch of 0.8 thread $/ \mathrm{mm}$. Tool rotational speed of $1000 \mathrm{rpm}$ and $1500 \mathrm{rpm}$, welding speed of 10 $20 \mathrm{~mm} / \mathrm{s}$ were the selected process parameters. Severe grain coarsening was noted in The Stir zone, Thermo mechanically affected zone and heat affected zone during welding. Microstructural analysis shown that the stirred zone contained $\mathrm{Al}_{8} \mathrm{Mn}_{5}$ and $\beta-\mathrm{Mg}_{17} \mathrm{Al}_{12}$ particles similar to that in base metal. A hardness trough was obtained in the friction lap welded AZ31B-H24 Mg alloy. The stir zone exhibits lowest hardness values of $72-82$ pct. of base metal. The tool rotational rate and welding speed had a greater influence on the failure loads of friction stir lap welds.Sevvel.P, Jaiganesh V [5] in 2014 experimented on the characterization of mechanical properties and microstructural analysis of AZ31B $\mathrm{Mg}$ alloy during friction stir welding and optimization. During that year majority of works are concentrated on AZ31B Mg alloys.( in wt.\% $\mathrm{Al} 2.37, \mathrm{Zn} 0.72, \mathrm{Mn} 0.30, \mathrm{Cu} 0.05, \mathrm{Si} \quad 0.08, \mathrm{Fe} \quad 0.005, \mathrm{~N} 0.005$ bal Mg).A detailed investigation was carried out to find out the influence of optimized process parameters on resultant joints.HSS tool with a tapered cylindrical profile was used. Maximum tensile strength was obtained at a tool rotational speed of $1000 \mathrm{rpm}$, welding speed of $0.5 \mathrm{~mm} / \mathrm{min}$.The detailed microstructure analysis revealed that the grain fragmentation was good and obtained uniform orientation.S.Mironov T.Onuma et.al.[4] in 2015 also concentrated o AZ31 Mg alloy but on varying welding temperatures.AZ31 Mg alloy is having a hexagonal close packed structure was examined. Tool steel with a shoulder diameter of $15 \mathrm{~mm}$,pin length of $3.7 \mathrm{~mm}$,tilt angle of $3^{\circ}$,plunge depth of $3.5 \mathrm{~mm}$ was used. A temperature range of $0.57-0.85 \mathrm{Tm}$ was used. Due to the HCP structure the maximum misorientation across grain boundaries could not exceed $30^{\circ}$.The lowering of temperature from $0.85 \mathrm{Tm}$ to $0.64 \mathrm{Tm}$ during Friction stir welding had led to an increase in tool load.

Bhukya srinivasa naik et.al.[3] in 2015 experimented on the tensile properties and residual stresses on friction stir welded AZ31B-H24 Mg alloy( in wt\% Al 2.5-3.5,Zn 0.7-1.3, Mn 0.2-1.0 bal Mg. Tool rotational speed and welding speed were the selected process parameters with ranges from $1000-1500 \mathrm{rpm}$ and $10 \& 20 \mathrm{~mm} / \mathrm{s} . \mathrm{H} 13$ tool with shoulder diameter $19.05 \mathrm{~mm}$,pin diameter of $6.35 \mathrm{~mm}$, thread length of $4.45 \mathrm{~mm}$,thread spacing of $1.27 \mathrm{~mm}$,pitch of 0.8 thread $/ \mathrm{mm}$, tilt angle $0.5^{\circ}$ was used for experimentation. The results proved that the tool rotational rate and welding speed had strong effect on tensile shear failure load. When the test temperature was increased the energy absorbed during tensile sear loading had also increased. The detailed fractographic analysis indicates that crack initiation was observed from the stress concentration zone.Jaiganesh.V, P.Sevvel [2] in 2015 experimented on the effects of process parameters on the microstructure and mechanical properties of $\mathrm{Mg}$ alloy. The alloy grade chosen for purpose was AZ80A $\mathrm{Mg}$ alloy( in wt\% Al 7.8, Zn 0.7, Mn 0.3,Cu 0.05,Si 0.1,Fe 0.005, Ni 0.005 bal $\mathrm{Mg}$ )A tapered cylindrical pin profiled High speed steel tool was used for friction stir welding with tool rotational speed, feed rate and constant axial force as the process parameters. A defect free sound weld was obtained at a tool rotational speed of $100 \mathrm{rpm}$ and feed rate of $1.5 \mathrm{~mm} / \mathrm{minute}$ 
microstructural analysis resulted in proper distribution of fine grains in the stir zone. Also high yield strength and superior mechanical properties were obtained. Prakash kumar sahu,Sukhomay pal[1] in 2015 used multi response optimization of process parameters during friction stir welding of AM20 Mg alloy with the help of taguchi grey relational analysis.( in wt.\% Al 2.03,Mn $0.43, \mathrm{Zn} 0.18, \mathrm{Si} 0.04$ bal $\mathrm{Mg}$ ). The process parameters chosen were tool rotational speed, welding speed, shoulder diameter and plunging depth.H13 tool steel was used having shoulder diameter of $16-24 \mathrm{~mm}$,pin diameter of $6 \mathrm{~mm}$,pin length of $3.5 \mathrm{~mm}$. Taguchi's $\mathrm{L}_{18}$ factorial design has been used in this work eight weld quality parameters ultimate tensile strength, yield strength, percentage elongation, compressive stress, bending angle, average hardness at nugget zone,thermomcehcnical zone and heat affected zone were calculated. A plunge depth of $0.12 \mathrm{~mm}$, rotational speed of $1100 \mathrm{rev} / \mathrm{min}$,welding speed of $98 \mathrm{~mm} / \mathrm{min}$, shoulder diameter of $24 \mathrm{~mm}$ yielded optimum results. From response surface methodology it was found that shoulder diameter and welding speed were having most influence.Eventhough the review period is short this paper will be a ready reference for upcoming researchers

\section{CONCLUSION}

In this work Friction stir welding of various types of $\mathrm{Mg}$ alloy grades has been considered. The influence of each process parameters on final weld quality, microstructural analysis, mechanical properties etc. have also been considered. Among various grades of $\mathrm{Mg}$ alloy AZ31 grade has been used in major. The process parameters selected were mainly Tool rotational speed, Welding speed, tool tilt angle etc. Thorough literature review related to Friction stir welding of Mg alloys has been done from 2009 to 2015.The works of various researchers has been highlighted throughout the paper. Remarks of various works are also highlighted.

\section{REFERENCES}

1. Prakash kumar sahu, Sukhomay pal (2015) Multi response optimization of process parameters in friction stir welded AM20 Mg alloy by taguchi grey relational analysis, Journal of $\mathrm{Mg}$ and alloys 3 36- 46.

2. V.Jaiganseh,P.Sevvel (2015), Effect of process parameters on Microstructural characteristics and mechanical properties of AZ80A Mg alloy during Friction stir welding, The Indian Institute of Metals 68:S99-S104.

3. Bhukya Srinivasa Naik et.al.(2015),Residual stresses and tensile properties of Friction stir welded AZ31B- H24 Mg alloyin lap configuration, The Minerals, Metals and Materials society.

4. S.Mironov et.al.(2015),Microstructure evolution during Friction stir welding of $\mathrm{AZ31} \mathrm{Mg}$ alloy,ActaMaterialia301-312

5. Sevvel P, Jaiganesh V (2014), Characterization of mechanical properties and microstructural analysis of Friction stir welded AZ31B Mg alloy through optimized process parameters, Procedia Engineering 97: 741-751.

6. B.S.Naik, D.L.Chen et.al (2014), Texture development in a Friction stir lap welded AZ1B Mg alloy, The Minerals, Metalsand Materials society.

7. Yong zhao et.al.(2014),Microstructure and mechanical properties of Friction stir welded MG2Nd- 0.3Zn- 0.4Zr Mgalloy,ASMinternational JMEPEG 23:4136-4142.

8. S.Ugender, A.Kumar et.al (2014), Microstructure and mechanical properties of AZ31B $\mathrm{Mg}$ alloy by Frictionstir welding, Procedia materialscience 6:1600-1609.

9. Inderjeet Singh, Gurmeet Singh Cheema et al.(2014),An experimental approach to study the effect of welding parameters on similar friction stir welded joints of $\mathrm{AZ} 31 \mathrm{~B}-\mathrm{O} \mathrm{Mg}$ 
alloy,Procedia engineering 97:837-846.

10. S.Rajakumar, A.Razalrose (2013),Friction stir welding of AZ61A Mg alloy, Advanced manufacturing technology68: 277-292.

11. S.H.Chowdhury et al.(2012),Friction stir welded AZ31 Mg alloy, microstructure, texture and tensile properties, The minerals, metalsand materialssociety.

12. A.Razal rose, K.Manisekar et.al.(2011),Influences of welding speed on tensile properties of Friction stir welded AZ61A Mgalloy.JMEPEG 21:257-265.

13. K.L.Harikrishna Et.al.(2010),Friction stir welding of Mg alloy ZM21,Transactions of the indian institute of metalsvol 63.807-811.

14. G.Padmanabhan, V.Balasubramanian (2009) ,An experimental investigation on friction stir welding of AZ31BMgalloy. Journalofadvanced manufacturingtechnology49:111-121.

15. R.S.Pishevar et.al. (2015) Influences of friction stir welding parameters on microstructural and mechanical properties of AA5456 (AlMg5) at different lap joint thicknesses.JMEPEG DOI: 10.1007/S11665-015-1683.

16. A.Kouadri-henni et.al.( 2014) Mechanical properties, microstructure and crystallographic texture of Magnesium AZ91-D alloy welded by friction stir welding. Metallurgical and materials transactions vol 45A.

17. Sevvel .P et.al. (2014) characterization of mechanical properties and microstructural analysis of friction stir welded AZ31B $\mathrm{Mg}$ alloy through optimized process parameters.procedia engineering 97:741-751.

18. J.Yang, D.R.Ni et.al.(2013) Strain controlled low cycle fatigue behavior of friction stir welded AZ31 Magnesiumalloy. Metallurgicalandmaterialstransactionsvol 45A.

19. J.Yang et.al.(2012) Effects of rotation rates on microstructure, mechanical properties and fracture behavior of friction stir welded AZ31 Magnesium alloy. Metallurgical and materials transactions vol 44A.

20. Lechoslaw Tuz et.al. (2011) Friction stir welding of AZ-91 and AM lite magnesium alloys.Welding international ISSN:0950-7116.

21. Kazuhiro Nakata (2009) Friction stir welding of magnesium alloys. Welding international ISSN: 0950- 7116.

22. B.Ratna sunil et.al.(2015)Joining of AZ31 and AZ91 Mg alloys by friction stir welding. Journal of magnesiumand alloys.

23. Juan chen et.al.(2015)Double sided friction stir welding of magnesium alloy with concaveconvex tools for texture control. Materials and design, Elsevier publications vol 76.

24. H.M.Rao et.al.(2015)Friction stir spot welding of rare earth containing ZEK 100 magnesium alloy Materialsand design, Elsevierpublications vol 56.

25. A.Dorbane et.al.(2015)Mechanical. Microstructural and fracture properties of dissimilar welds produced by friction stir welding of AZ31B and Al6061.material science and engineering: A Elsevier publications.

26. R.Z.Xu et.al.(2015) Pinless friction stir spot welding of Mg-3Al-1Zn alloy with interlayer journal of material science and technology elsevier publications.

27. S.Malopheyev et.al.(2015) Friction stir welding of ultra fine grained sheets of Al-Mg-Sc-Zr alloy ,Materials science and engineering A: vol 624 : 132-139. Elsevier publications.

28. H.M.Rao et.al.(2015) Effect of process parameters on microstructure and mechanical behaviors of friction stir linear welded Aluminium to Magnesium, Material science and engineering :A vol 651:27- 36.elsevier publications.

29. Banglong $\mathrm{Fu}$ et.al.(2015)Friction stir welding process of dissimilar metals of 6061-T6 aluminium alloy to AZ31B Mg alloy.Jurnal of material processing technology vol 218:3847,elsevier publications.

30. Mohammadi et.al.(2015) Friction stir welding joint of dissimilar materials between AZ31B magnesium and 6061 aluminium alloys: microstructure studies and mechanical charectarizations,material characterization vol 101:189-207,elsevierpublications. 


\section{Authors}

Unnikrishnan M A received B tech in Mechanical Engineering from PRS College of Engineering affiliated to Kerala University in 2008 .He received his Masters from CSI Institute of Technology affiliated to Anna University Chennai in 2013.He is pursuing $\mathrm{PhD}$ in Mechanical Engineering from Noorul Islam University, Thuckalay Tamil nadu from 2014 onwards. He is working as Assistant professor in PRS College of Engineering. His areas of interest are Manufacturing, Welding and optimization.

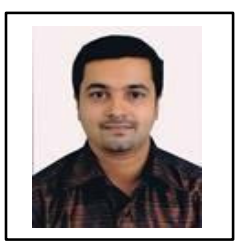

Edwin Rajadhas.J received his bachelor's degree from Noorul Islam college of Engineering in 2000.He obtained his masters from AKCE in 2002.He obtained his $\mathrm{PhD}$ from NIT Trichy in Intelligent Manufacturing in the year 2009.He had a teaching experience of over 10 years. He had published over 20 papers in various international journals. He is currently serving as professor and Head of department of Automobile Engineering. His areas of interest include intelligent manufacturing, optimization techniques, weldingetc.

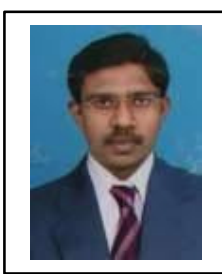

